\title{
Conviction of the Perpetrator of Land Grabbing in the Jurisdiction of Denpasar City Police
}

\author{
Cokorda Bagus Yudha Permana ${ }^{1}$, Simon Nahak ${ }^{2}$ and I Ketut Widia ${ }^{3}$ \\ \{yudha_permana@gmail.com, simon.nahak@gmail.com and ketut_widia@yahoo.com\} \\ Universitas Warmadewa, Denpasar, Bali - Indonesia
}

\begin{abstract}
Cases of land grabbing in Indonesia over the past decade dominated the civil cases. Despite the rules governing land affairs that have been established and even amended, land grabbing have not effectively been settled. Through an empirical study approach, we examined the leading factors and procedures for implementing the provisions of convicting the perpetrators of land grabbing in the jurisdiction of Denpasar City Police of Bali Indonesia. We collected data from the Denpasar City Police office through interview and documentation study. At the end of the data analysis, we discovered that in spite of having implemented the provisions of land accordingly, the individual's desire to gain profits and change in the city order as a result of migration was the internal and external factors of land grabbing. The demand to make a land certificate in order to obtain fixed legal status for each landowner is urging the government.
\end{abstract}

Keywords: City police; conviction; land grabbing

\section{Introduction}

The cases in the land sector are the ones that often create big challenges for the government and the people in several countries to face [1][2], including Indonesia. Land grabbing is one of the most widespread disputes that have triggered the loss of welfare and peace in the lives of community members [3] in Indonesia. Until September 2013, according to data from the Indonesian National Defense Agency, the number of land cases reached 4,223 cases, consisting of 1,888 the remaining cases in 2012 and as many as 2,335 new occurred cases. Of which there were only 2014 cases or $47.69 \%$ spread across 33 provinces throughout Indonesia that were legally resolved [4]. Of all those cases, East Java was the fourth largest contributor, namely 287 cases and Malang Raya is the majority contributor, which is $50 \%$ of the cases.

Land disputes have had various impacts on the economic, social and environmental sectors [5]. In the economic sector, the dispute has forced the parties involved to incur excessive costs. The longer the dispute resolution process takes place, the greater the costs must be incurred by the parties concerned. The social impact of disputes in the land sector is the occurrence of social estrangement among citizens, including obstacles to the creation of cooperation between them $[4$, 5]. One of the most often occurred land disputes is land grabbing [7]. Unauthorized land grabbing does harm anyone, especially if the land is used for business purposes. There are various types of 
illegal land grabbing that often occur, such as physical land occupation, land cultivation, sale of land rights, etc.

In Indonesian state criminal law, the provisions concerning land grabbing are regulated in Article 2 of Law Number 51 Prp of 1960 concerning Prohibition of Use of Land without Permit from Rights or Proxy (Law No. 51 Prp 1960) which determines that land use is not licensed the right or legitimate power of attorney is prohibited, and can be threatened with imprisonment for a maximum of 3 months, or a fine of up to Rp 5,000 (five thousand Rupiah) as stipulated in Article 6 of Law No. 51 Prp 1960. Unfortunately, even though this law exists, to date, among the people, land grabbing cases have not been able to be dealt with effectively, even at the judicial level. This can be seen when a court decision on a criminal case regarding land grabbing cannot be used to execute land that is disputed or grabbed, because the criminal decision is to punish the person who grabbed the land, so that the land ownership rights in general must still be settled through a lawsuit.

We thought that disputes regarding land grabbing should have not occurred continually, so that they break through the welfare of the real owners of the land and pose a big challenge for the government to find a solution. Therefore, in this study we identified the provisions and implementation of provisions on land grabbing to determine the factors that cause such continuing land grabbing, so that from what will be found, strategic solutions could be designed and implemented.

We designed the study by applying empirical legal research method. Our study data were collected from Denpasar City Police Office. Literature study was carried out to collect information about land cases in general and land grabbing cases to determine the condition of the number of cases that had occurred, cases that were resolved, and the ones ongoing settlements. In addition, we interviewed the Denpasar Resort Police Chief to obtain legal provisions governing Land Appropriation as well as obstacles that arose and were difficult to resolve. In addition, we collected articles of Indonesian law governing Land, such as the Law of the Republic of Indonesia Number 51/Prp/Year 1960 concerning Prohibition on the Use of Land without Permits from Owner or Proxy. We, then, analyzed the data descriptively, i.e. we outlined the legal provisions governing the land sector in Indonesia and the implementation of the legal provisions and wrote down the factors that trigger land grabbing.

\section{Results and Discussion}

\subsection{Leading Factors to Land Grabbing in the Jurisdication of Denpasar City Police}

Land is one of the natural resources that are important for the survival of many people. In Indonesia, the state has power over land pursuant to Article 33 paragraph (3) of the 1945 Constitution of the Republic of Indonesia. State ownership rights over land are further enacted in the Basic Agrarian Law (Indonesian term is UUPA), as the state's highest right to all land in Indonesia. The land controlled by the state is then diverted partially from its use and control to third parties for development and settlement purposes, without the state having to lose the assets of the state land, and to ensure legal certainty over land ownership with management rights [8]. Land management rights have a correlation with the term land rights. Land rights, according to Article 4 
paragraph (2) of Law No. 5 of 1960 concerning UUPA, stated that "land rights are rights that contain the authority to use the land in accordance with its interests as long as not in conflict with applicable legal regulations".

The act of land grabbing is indeed an act that is prohibited by the applicable laws and regulations. In Indonesia, the prohibition on acts of land grabbing is contained in Article 2 of Government Regulation in Lieu of Law Number 51 of 1960 concerning Prohibition of Use of Land without Permit from the Owner or Proxy, which regulates, "It is forbidden to use land without permission from those who are entitled or having legitimate rights." Furthermore, in Article 6 paragraph (1), (2) and (3), it is regulated that the act of using land without permission from the owner entitled or proxy is threatened with imprisonment sanctions for a maximum of 3 months or a maximum fine of Rp. 5000, - (five thousand rupiah). It is also explicitly stated that such form of criminal acts is classified as a violation.

The word "entitled" in Article 2 a quo refers to the ownership of a person or individual to control or use a plot of land. Such ownership is indicated by a certificate of land rights. Fitgerald describes the characteristics of ownership rights with the following: 1) The owner has the right to own the objects; 2) The owner usually has the right to use and enjoy the objects he owns; 3 ) The owner has the right to spend, damage or transfer the objects; 4) Ownership has characteristics that do not recognize the time limit; and 5) Ownership has residual characteristics [9].

Unlike the concept of the right to control or (hold) a position of power or bezit, Article 529 Buergerlijk Wetboek (BW) states, "a position in power is the position of someone who controls a material, both with himself and through other people, and with people who maintain or enjoy it as the person who has the material".

The ruler can only take action on land owned by another person for a certain period of time (not forever). In fact, it could be, a piece of land, controlled by someone, but judicially the material property relationship (object) is only with the subject ownership rights). Next, it can also be identified that land ownership by other people, other than the owner of land rights, can be in a legal condition (with the owner's permission) and can also be in an illegal condition (without the owner's permission). This happens because the concept of mastery is the right of use of objects (land) with a time limit, so that the mastery will end if the holder of land title is anxious to it.

The provisions of Article 6 of Law Number 51 Year 1960 provide a limitation regarding acts which are considered as acts that are prohibited because of the act of using land without permission from the entitled person. Some prohibited acts, which are classified as land grabbing, are:

a. Utilize a plot of land without permission that is from the right or legitimate proxy;

b. Interfere with those who have the right or who have legitimate power in using their rights to a plot of land;

c. Order, invite, persuade or advocate by oral or written means to execute land utilization without permission from the entitled person; and

d. Give assistance in any way to execute land utilization without permission from the entitled one.

Based on the provisions of Article 6, it can be stated that Law Number 51 of 1960 concerning Prohibition of Use of Land without Permit from the Entitled Person or the Proxy contains four formulations of offenses whose elements are as follows:

a. Formulation of offenses Article 6 paragraph (1) a: 
- Anyone;

- Utilize land without permission from those entitled person or proxy (except the use of plantation and forest lands according to Emergency Law Number 8 of 1954 in conjunction with Emergency Law Number 1 of 1956, which will then be settled according to provisions set forth by the agrarian minister);

- Sentenced to a maximum sentence of 3 months and/or a maximum fine of Rp. 5,000 (five thousand rupiah)

b. Formulation of offenses Article 6 paragraph (1) b:

- Anyone;

- Interfere with those who are entitled or proxy to utilize their rights to a plot of land;

- Sentenced to a maximum sentence of 3 months imprisonment and / or a maximum fine of Rp. 5,000 (five thousand rupiah).

c. Formulation of offenses Article 6 paragraph (1) c:

- Anyone;

- Order, invite, persuade or advocate;

- Oral or in written to utilize the land without permission from those who are entitled/proxy, or who interfere with those who are entitled/proxy in exercising their rights over a plot of land;

- Sentenced to a sentence of imprisonment for a maximum of 3 months and/or a fine of up to Rp. 5,000 (five thousand rupiah).

d. Formulation of offenses Article 6 paragraph (1) d:

- Anyone;

- Provide assistance in any way to utilize the land without permission or by interfering with those who are entitled (authorized proxy) in utilizing their rights to a plot of land;

- Sentenced to a maximum sentence of 3 (three) months and / or a maximum fine of Rp.5,000 (five thousand rupiah) [10].

Thus, the act of land grabbing encompasses the control to a plot of land without the permission of the owner, interfering with the control of the legal landowner and participating in controlling a plot of land without the permission of the owner [11]. The right to control the land which lasts for quite a long time accompanied by supervision or less attention from the land owner, or because the enforcer of the right to land dies, and then the heir does not know very well the existence of the land of his parents. Some forms of these conditions can be an opportunity, in which it is the opportunity is one of the reasons for the desire to commit acts against the law (land grabbing).

Theoretically, the act of criminal acts of land grabbing in such a situation is very likely to occur [12]. This is in line with the view in classical theory that humans have the ability as a calculator. Humans will choose to do or not do with consideration of pleasure or not pleasure. Humanly, it can be justified that humans will always seek or do everything they believe will bring pleasure to them [13]. In the context of this research, it can be justified that the behavior of land grabbing is carried out by the perpetrator on an existing occasion. The support from circumstances (time of mastery, landowners have inherited, closeness to landowners so as to gain mastery of trust) is a condition that is befalling the perpetrator before acts of unlawfulness occur. 
Circumstances that provide an opportunity for the perpetrators to bring up the choice of being criminals (in this context are attempts to grab the land) or not being criminals [3]. After making a consideration, the results are achieved that "if the perpetrator can own the land that he is in possession of, or transfer the ownership rights of the land under his control, he will benefit economically, labor and time from it" The economic benefits, energy and time imagined will certainly bring pleasure in the life of the perpetrator.

Regardless of the classical view, the crime of land grabbing in the resort area of the Denpasar city police can be seen in terms of sociology. Adhering to anomie theory, Emile Durkheim, as quoted by Topo Santoso and Eva Achjani, stated the following:

"One of the ways to study a society is to look at its component parts to find out how each of them relates to each other. In other words, we see the structure of a society to determine how it functions. If society is stable, its parts operate smoothly and social arrangements function. Such a community is characterized by integration, cooperation and agreement. However, if the component parts are especially in a situation that endangers social order/order, the structure of society is to be dysfunctional [14]."

Based on the explanation, it can be seen that the theories discussed emphasize the position of an individual (actor) as part of a society. Individual evil behavior is caused by changes in the structure of society, which will cause shock. The intended shock will affect the behavior of individuals in the community.

The influence of the advancement of science and technology brings about great impacts on the economy and the increasing urban population in the city of Denpasar, which now turns into changes in the structure of society; previously the noble values in society for mutual respect, trust in karma, social norms, religious norms and moral norms were developing, have been shifting [9]. The order of the city of Denpasar, which was previously synonymous with the order of rural areas, has now shifted along with developments that have brought major impacts to the changes of the society's order into the condition of a globally advanced society. The limited range of available resources results in tight social and economic competition between individuals or groups [15]. If equated with the present study object, in the period before the urban period, Denpasar city was still inhabited by indigenous people; as well as land is still very much and has not been used for other purposes besides plantations and agriculture. During the green days, there were many individuals who had more than a plot of plantation land location so that they requested the help of 'sharecropper' to control and cultivate the land so that it would bring economic results.

Along with the development of society and changes in the fabric of society, the sharecroppers increasingly feel the distresses in the economic field. The existence of land in developing communities is increasingly felt to be very important [16]. Land has a high value, which not everyone can afford to own a plot of land on their own rights. With the opportunity to master a land court, the desire to own the land that has long been controlled has arisen. The traditional society order that is identical with dense religious, moral and modesty norms are no longer considered [6]. The opportunity is then used to carry out actions classified as the acts of land grabbing. In these circumstances, it can be said that there has been a malfunction of the social structure or dysfunctional order which has resulted in land grabbing.

2.2 Law Enforcement for Land Grabbing Perpetrators in the Jurisdication of Denpasar City Police 
Law enforcement is all the effort to describe legal rules into people's lives, so, thus, the legal objectives for society are the manifestation of values of justice, equality, legal certainty, protection of rights, order, happiness of society, etc. can be achieved [17].

It has been explained in the previous section that the subject of the prohibition on land grabbing is contained in several laws and regulations both within the Criminal Code and its outside. All these rules constitute a unity of law that is integrated into a system called the legal system. In line with Freidman's opinion, law enforcement with a system approach includes several influential components in it. Not only the substance or the rule of law, but there are structures and cultures. Friedman's opinion about the legal system as quoted by Ali, the legal system consists of elements which include:

a. The legal substance is the overall legal rules, legal norms and legal principles, both written and unwritten, including court decisions.

b. The legal structure, namely the entire legal institutions that exist and their apparatus, includes, among others, the police with police officers, judiciary with prosecutors, courts with judges, and others.

c. Legal cultures, namely opinions, trusts (beliefs), habits, paradigms, and ways of acting, both from law enforcers and from citizens, about law and various phenomena related to law [18].

Law enforcement against perpetrators of criminal acts of land grabbing in the resort police law area of the city of Denpasar certainly cannot only refer to laws and regulations governing the prohibition of land grabbing. Another component that has an equal position is law enforcement. Law enforcers referred to are every institution incorporated in the criminal justice system. The criminal justice system is a process stage that must be passed by someone to be convicted. Law enforcement against criminal acts of land grabbing in Denpasar is carried out by the resort police of Denpasar city.

In line with the Denpasar Police Resort's vision and mission, the police have the authority to handle criminal cases as stated in the Criminal Code and other laws and regulations unless specifically regulated regarding the authority of investigations and examinations in certain cases as stated in the legislation outside Criminal Code. Regarding the criminal act of land grabbing arranged into a general criminal offense in the Criminal Code (Article 167 or 385), the authority for investigation and examination becomes the authority of the Police of the Republic of Indonesia. In the case of a criminal act occurring in the jurisdiction of the Denpasar City Police, the police force has the authority to deal with it.

Based on the Criminal Procedure Code, police authority includes investigating and examining. The Investigator is any state police official of the Republic of Indonesia. According to Article 5, investigators have relatively broad authority in receiving reports and investigating criminal acts. The definition of investigation according to Law No. 8 of 1981 concerning Criminal Procedure Law is a series of investigative actions to seek for and find an event that is suspected of being a criminal offense in order to determine whether or not an investigation is conducted according to the method stipulated in this law. From this concept, it is clearly understood that essentially an investigation is the determination of an act to be a crime or not. When an act has been deemed valid as a criminal act, then an investigation can be executed. The process of the investigation is usually carried out by the Police of the Republic of Indonesia and for certain cases, it can also be carried out by the prosecutor. At context of situation, someone is called a suspect. 
According to article 1 point (1) of the Criminal Procedure Code, investigators are state police officers of the Republic of Indonesia or officials of Civil Servants who are given special authority by the Act to conduct investigations. For this reason, investigators have the following authority:

a. receive a report or complaint from someone about a crime;

b. carry out the first action when at the scene of the incident;

c. command to stop a suspect and examine the suspect's personal identification;

d. make arrest, detention, search and seizure;

e. conduct inspection and seizure of letters;

f. take fingerprints and photographing someone suspected of committing a criminal act;

g. call people to be heard and examined as suspects or witnesses;

h. bring in an expert who is needed in connection with the case examination;

i. hold a termination of investigation;

Whereas, in article 6 paragraph (2) of the Criminal Procedure Code, it is said:

"The investigator referred to in article 6 paragraph (1) letter (b) has the authority in accordance with the Law which becomes their respective legal basis and in the implementation of their duties, it is under the coordination and supervision of the investigator mentioned in article 6 Paragraph (1), letter (a) Criminal Procedure Code.”

Meanwhile, an investigation is a series of investigative actions in terms of and according to the methods stipulated in the law, to search for and collect evidence and with that evidence it makes revealed about the crime that occurred to determine the suspect [19]. The purpose of the investigation is to appoint who has committed a crime and to provide evidence of the wrongdoing. To achieve this purpose, the investigator will collect information with certain facts or events" In practice, the investigation in the jurisdiction of the Denpasar City Police took place after the crime of land grabbing to obtain information about [20]:

a. What type of crimes has been committed by the alleged perpetrator has grabbed the land

b. When the criminal act of land grabbing was committed

c. Where the crime was committed

d. By what the crime was carried out

e. How the crime was committed

f. Why the crime was executed

g. Who the perpetrators were

Suspicion or knowledge of the occurrence of criminal acts of land grabbing can be obtained by the parties, in this case by the Denpasar City Police Department through several sources or methods. Sabuan classifies police recognition sources of actions that indicate criminal acts into several conditions [21]:

a. Being red-handed (ontdekking op heterdaad)

Being red-handed (op heterdaad) means:

- The arrest of someone when he is committing a crime

- The arrest takes place immediately for a while after the crime was committed

- A moment later the public called for a perpetrator commiting it, or

- If a moment later it is found that the object allegedly has been used to commit the crime indicating that he is the culprit or has committed or helped commit the crime

b. Out of being red-handed (buitan ontdekking op heterdaad) 
In the case of not being red-handed, the recognition of the investigators regarding the execution of a criminal act can be obtained from:

- Report (aangifte)

- Plaint (klacht)

- Own recognition by investigator

In settling the land grabbing dispute in the Denpasar City Police, the community and the police also looked at the perspective of the victim where in the land grabbing, the losers were victims. Influenced by cultural values and local wisdom of Bali, some communities are aware that criminal punishment is not only a means to repay the actions of the perpetrators, to ensnare the perpetrators and/or to prevent similar incidents in the future. In the realm of criminal law [8], the interests of victims are represented by the state, the authority of prosecution and imposition of criminal sanctions on perpetrators represented by the state. However, the interests of victims are still not represented. As a result, the settlement of criminal acts of land grabbing is carried out by the mediation method.

Damaged conditions are intended to be perpetrators who experience material or immaterial losses from land grabbing experienced. Retaliation and entrapment of perpetrators through the reasoning mediation mechanism is fulfilled with compensation and apologies for the perpetrators of land grabbing against their victims. It can be observed that the reasoning mediation rates that have been carried out in the area of the Denpasar City Police show responsiveness from police investigators.

Table 1. The Settlement of Land Grabbing Cases at the Denpasar City Police.

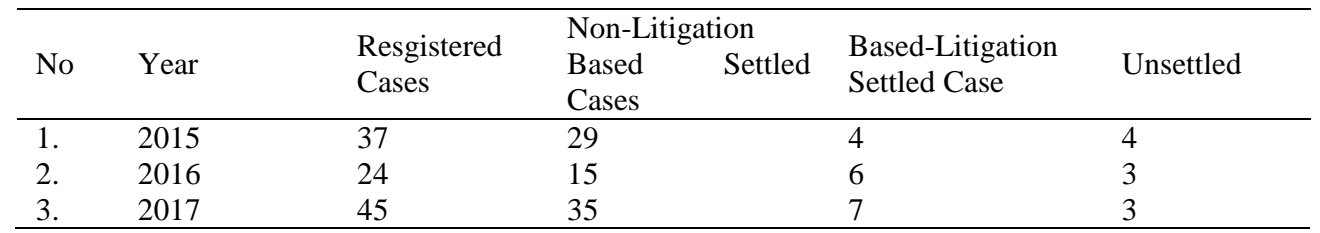

Source: Data from the Criminal Investigation Division of the Denpasar City Police

The rate of settlement of land grabbing cases through mediation in Table 1 shows the police attitude that responds well to the wishes of the people who do not want to continue their case regarding the crime of land grabbing experienced and attitudes that respond to the results of dialogue between perpetrators and victims in the mediation efforts. Although a case has been processed by imposing a crime on the perpetrators of land grabbing, the feelings of revenge and losses suffered by the victim are certainly not easily replaced [5].

The judicial process with the imposition of criminal acts on the perpetrator is never able to fulfill a sense of justice for the victims of the criminal act of land grabbing. Settlement of criminal acts of land grabbing through the practice of the court will only produce a verdict with criminal conviction for the perpetrator. Mediation in this kind of crime, in addition to aiming to recover the loss of the victim and the disturbed condition resulting from the criminal act, is also intended to touch the humanitarian values, morals and responsibilities of the perpetrator so as not to repeat the evil deeds. 


\section{Conclusion}

Leading factors to criminal act of land grabbing in the jurisdiction of the Denpasar City Police originate from inward soul and outward realm of the perpetrators. From the inward soul, the desire arises from consideration of profit and loss or a sense of pleasure and pleasure in the mind of the perpetrator. Outward realm is the changes in urban order, high economic and social values compared to land rights accompanied by changes in urban society, so this causes the perpetrators to commit unlawful acts through land grabbing.

The law enforcement procedure for the perpetrators of land grabbing in accordance with the laws and regulations is carried out through several stages: starting from the existence of complaints from the public about the crime of land grabbing, then followed up by conducting an investigation into the land grabbing case. The estuary of this process is the complete Minutes of Examination of the suspect of land grabbing and then handed over to the Prosecutor's Office. In addition to litigation methods, the Denpasar City Police Resort applies a mediation method (nonlitigation) in resolving land grabbing cases. This method is used because it touches on the value of humanity, community justice and the responsibility of the perpetrators of land grabbing.

\section{References}

[1] Borras, S, M, Franco, J, C and Wang, C.: The Challenge of Global Governance of Land Grabbing: Changing International Agricultural Context and Competing Political Views and Strategies. Globalizations. vol. 10 (1). pp. 161-179 (2013)

[2] Sakolski, A, M.: The Great American Land Bubble: The Amazing Story Of Land-Grabbing, Speculations, and Booms from Colonial Days to the Present Time. vol. 10 (4). pp. 36-37 (1966)

[3] Hall, R.: Land grabbing in Southern Africa: The many faces of the investor rush. Rev. Afr. Polit. Econ. vol. 38 (128). pp. 193-214 (2011)

[4] Data Badan Pertanahan Nasional Pusat tahun (Data from the Central National Land Agency in 2013. Retrieved from http://www.bpn.go.id/ accessed on April 20 (2017)

[5] Akram-Lodhi, A, H.: Contextualising land grabbing: Contemporary land deals, theglobal subsistence crisis and the world food system. Can. J. Dev. Stud. vol. 33 (2). pp. 119-142 (2012)

[6] Klopp, J, M.: Pilfering the Public: The Problem of Land Grabbing in Contemporary Kenya. Afr. Today. vol. 47 (1). pp. 7-26 (2000)

[7] McMichael, P.: Land Grabbing as Security Mercantilism in International Relations. Globalizations. vol. 10 (1). pp. 47-64 (2013)

[8] Soerodjo, I.: Hukum Pertanahan Hak Pengelolaan Atas Tanah (HPL): Eksistensi, Pengaturan dan praktik. Yogyakarta. Laksbang Mediatama (2014)

[9] Suwitra, I, M.: Eksistensi Hak Penguasaan dan Pemilikan Atas Tsanah Adat di Bali: Dalam Perspektif Hukum Agraria Nasional. Bandung. Logoz Publishing (2014)

[10] Suandra, I, W. Hukum Pertanahan Indonesia. Jakarta. Rineka Cipta (1994)

[11] De Schutter, O.: How not to think of land-grabbing: Three critiques of large-scale investments in farmland. J. Peasant Stud. vol. 38 (2). pp. 249-279 (2011)

[12] Margulis, M, E, McKeon, N and Borras, S, M, J.: Land grabbing and global governance. Special Issue. Globalizations. vol. 10 (1). pp. 1-23 (2013)

[13] Lilly, C, R and Al, E.: Teori Kriminologi: Konteks dan Konsekuensi. Jakarta. Prenada Media Group (2015)

[14] Santoso, T and Sulva, E, A.: Kriminologi. Jakarta. PT. Raja Grafindo Persada (2002)

[15] Borras, S, M and Franco, J, C.: Global land grabbing and trajectories of Agrarian change: A 
preliminary analysis. J. Agrar. Chang. vol. 12 (1). pp. 34-59 (2012)

[16] Borras, S, M, Kay, C Gomez, S and Wilkinson, J.: Land grabbing and global capitalist accumulation: Key features in Latin America. Can. J. Dev. Stud. vol. 33 (4). pp. 402-416 (2012)

[17] Fuady, M.: Aliran Hukum Kritis: Paradigma Ketidakberdayaan Hukum. Bandung. Citra Aditya Bhakti (2003)

[18] Ali, A.: Menguak Teori Hukum (Legal Theory) dan Teori Peradilan (JudicialPrudence) Termasuk Interpretasi Undang-undang (Legisprudence). Jakarta. Kencana Prenada Media Group.

[19] Wisborg, P.: Human Rights Against Land Grabbing? A Reflection on Norms, Policies, and Power. J. Agric. Environ. Ethics. vol. 26 (6). pp. 1199-1222 (2013)

[20] Interview with I Gede Agus Suadarma NRP as Denpasar Criminal Investigator Criminal Investigator on Friday, December 15 (2017)

[21] Sabuan, A.: Hukum Acara Pidana. Bandung. Angkasa (1990) 